\title{
MicroRNAs Involved in Small-cell Lung Cancer as Possible Agents for Treatment and Identification of New Targets
}

\author{
ULRICH H. WEIDLE and ADAM NOPORA
}

\author{
Roche Pharma Research and Early Development, Roche Innovation Center Munich, Penzberg, Germany
}

\begin{abstract}
Small-cell lung cancer, a neuro-endocrine type of lung cancers, responds very well to chemotherapy-based agents. However, a high frequency of relapse due to adaptive resistance is observed. Immunotherapy-based treatments with checkpoint inhibitors has resulted in improvement of treatment but the responses are not as impressive as in other types of tumor. Therefore, identification of new targets and treatment modalities is an important issue. After searching the literature, we identified eight down-regulated microRNAs involved in radiation- and chemotherapy-induced resistance, as well as three up-regulated and four down-regulated miRNAs with impacts on proliferation, invasion and apoptosis of small-cell lung cancer cells in vitro. Furthermore, one upregulated and four down-regulated microRNAs with in vivo activity in SCLC cell xenografts were identified. The identified microRNAs are candidates for inhibition or reconstitution therapy. The corresponding targets are candidates for inhibition or functional reconstitution with antibody-based moieties or small molecules.
\end{abstract}

Small-cell lung cancer (SCLC) is an exceptionally lethal malignancy comprising $13-15 \%$ of all lung cancer (1), with 250,000 cases diagnosed annually worldwide (1). SCLC is highly sensitive to platinum-based chemotherapy, topoisomerase inhibitor etoposide, and to lurbinectidin, a recently approved DNA binder $(2,3)$. However, disease

This article is freely accessible online.

Correspondence to: Adam Nopora, Roche Diagnostics GmbH, Nonnenwald 2, D-82372 Penzberg, Germany. Tel: +49 8856602552, e-mail: adam.nopora@roche.com; Ulrich H. Weidle, Roche Innovation Center Munich, Roche Diagnostics GmbH, Nonnenwald 2, D-82372 Penzberg, Germany. Tel: +49 8856602552, e-mail weidle49@t-online.de

Key Words: Apoptosis, invasion, proliferation, metastasis, chemoresistance, microRNA-based therapy, new treatment modalities, target identification, review. recurrence and metastasis to the brain, adrenal glands, bone and liver after treatment remains an issue (2). Inactivating mutations in retinoblastoma $(R B)$ or TP53 are most commonly observed, however, these alterations are not druggable and, in contrast to non-small-cell lung cancer no tractable drivers or fusion proteins have been observed (4). Monoclonal antibodies nivolumab and pembrolizumab, directed against checkpoint inhibitors, have been approved as first-line treatment of SCLC together with chemotherapy and for treatment of relapsed disease (5). However, the therapeutic benefit is not as pronounced as observed with other types of tumor (5). Furthermore, SCLC subtypes have been identified based on differential expression of transcription factors achaete-scute homolog (ASCL1), neurogenic differentiation factor (NeuroD1), yes-associated protein (YAP1) and POU class 2 homeobox 3 (POU2F3) (6). These subtypes might respond to drugs with different vulnerability (6). Several agents targeting T-cell immunoreceptor with Ig and ITIM domains (TIGIT), cytotoxic T-lymphocyte antigen 4 (CTLA4), or cyclindependent kinases 4 and 6 are in phase III clinical studies or under Food and Drug Administration review (7). Nevertheless, there is an urgent need to identify new targets and treatment modalities for SCLC. Here, we focus on microRNAs (miRs) as therapeutic agents and as tools for identification of SCLCrelated targets for therapeutic intervention.

\section{MicroRNAs - Role in Oncology}

miRs are synthesized by RNA polymersase II in the nucleus as precursor RNAs, processed and exported into the cytoplasm (8-10). One strand of a 22 nucleotides (nts) complex is maintained (guide strand), the other strand (passenger strand) is discarded (8-10). The guide strand binds to the 3'untranslated region of corresponding mRNAs and induces their degradation or inhibits their translation (8-10). A single miR can interact with several different mRNAs and therefore can interfere with several pathways and has the potential to rewire oncogenic pathways (11). miRs can exert an oncogenic or tumor-suppressive role, depending on the context (12). A 
tumor-suppressive role is mediated by $m i R-16-1$ and $m i R-15 a$ by targeting anti-apoptotic protein BCL2 apoptosis regulator (BCL2). Their deletion in mice causes B-cell chronic lymphocytic leukemia corresponding to the disease in humans and its cytogenetic characteristics $(13,14)$. The oncogenic role of miRs was demonstrated by induction of hepatocellular carcinoma through liver-specific expression of $m i R-221$ in transgenic mice (15). miRs can have an impact on all stages of carcinogenesis, including metastasis and anti-tumoral immune response (16). We recently summarized the impact of miRs on growth and metastasis of hepatocellular carcinoma (17), pancreatic cancer (18), non-small-cell lung carcinoma (19), breast cancer (20) and prostate cancer (21). In this review, we focus on the role of miRs with respect to chemoresistance, tumor growth and metastasis of SCLC.

\section{miRs Involved in Chemoresistance and Radioresistance of SCLC}

All of the miRs discussed are down-regulated in SCLCcancer related cell lines or clinical specimen in comparison to corresponding controls.

miR-7. $m i R-7$ (Figure 1) affects the multidrug-resistance protein ATP-binding cassette subfamily C member 1 (ABCC1) (22), inward-rectifier potassium ion channel 2.1 (KIR2.1) (23) and poly (ADP-ribose) polymerase 1 (PARP1) (24).

$\mathrm{ABCC} 1$ expression is inversely correlated with $m i R-7$ (22). $\mathrm{ABCC} 1$ is a transmembrane drug transporter containing three membrane-spanning domains and two cytosolic nucleotidebinding domains (25) and is expressed in many types of multidrug-resistant cancer (26). Overexpression of ABCC1 is predictive for resistance to chemotherapy in $\operatorname{SCLC}(27,28)$. A low-level expression of $m i R-7$ correlated with shorter overall survival in patients with SCLC (22). In the SCLC cell line H69AR, miR-7 down-regulation was shown to be responsible for resistance to adriamycin and etoposide $(22,29)$.

$m i R-7$ also targets KIR2.1, a member of the classical inward rectifying potassium channel family $(23,30-32)$. KIR2.1 was up-regulated five-fold in H69AR cells in comparison to H69 SCLC cells (23). KIR2.1 induced resistance to apoptosis following exposure to chemotherapeutic drugs (23). Overexpression of KIR2.1 in H69 and H466 SCLC cells enhanced their growth in immuno-deficient mice (23). Upregulation of miR-7 sensitized H69AR cells to adriamycin, cisplatin and etoposide (23). RAS-protein kinase C-mitogenactivated protein kinase (MEK) signaling was identified as an important inducer of KIR2.1, which was down-regulated by RAS-protein kinase $\mathrm{C}$ inhibitor staurosporine and MEK inhibitor UO126 (23).

PARP1 was identified as a target in doxorubicin-resistent SCLC cell line H69AR in comparison to H69 parental cells (24). PARP1 was resolved as a target of $m i R-7(24,34)$.
Inhibition of $m i R-7$ resulted in increased homologous repair in doxorubicin-resistant SCLC cells (24). $m i R-7$ reduced expression of breast cancer susceptibility protein 1 (BRCA1) and repair protein RAD51 homolog1 (RAD51), and discrupted homologous recombination-based repair, leading to doxorubicin resistance by targeting PARP1 (24). PARP1 has a multi-faceted role in DNA repair and chromatin remodeling (35). PARP1 inhibitors are approved anticancer agents based on a synthetic-lethality based mode of action (36-38).

$m i R-22$. $m i R-22$ (Figure 1) was down-regulated in NCI-466 SCLC cells and inhibited radiosensitivity by targeting Werner helicase-interacting protein-1 (WRNIP1) (39). WRNIP1 is an ATPase which can protect replication forks and co-operates with RAD51 to safeguard the integrity and maintenance of the genome (40-42). Overexpression of $m i R-22$ promoted apoptosis and inhibited migration of NCI-466 cells (39).

$m i R-24-3 p$. Autophagy is a strategy by which resistance to chemotherapy is conferred $(43,44)$. Etoposide- and cisplatin resistant SCLC cells exhibited increased autophagy (45). $m i R$ 24-3p (Figure 1) was down-regulated in SCLC cells and expression of autophagy-related $4 \mathrm{~A}$ cysteine peptidase (ATG4A) was blocked (45). Expression of $m i R-24-3 p$ can suppress autophagy of SCLC cells by directly targeting ATG4A (45). It has been shown that inhibitors of autophagy can sensitize chemoresistant cells to anticancer therapy in clinical trials $(45,46)$.

miR-100. miR-100 (Figure 1) was shown to target homeobox transcription factor HOXA1, which was associated with poor prognosis in patients with SCLC, and its down-regulation mediated chemoresistance (47). HOXA1 was found to be expressed in $46 \%(29 / 63)$ of tumors from patients with SCLC. Expression of miR-100 in multidrug-resistant SCLC cell line H69AR reversed resistance to cisplatin and etoposide (47). HOXA1 is involved in progression and prognosis of several types of tumor. It mediates tumor proliferation and poor prognosis in gastric cancer via cyclin D1 (48); enhances proliferation, invasion and metastasis of prostate cancer cells (49); and correlates with poor prognosis in patients with hepatocellular carcinoma (50).

miR-138. miR-138 (Figure 1) was down-regulated in SCLC tissues and three corresponding cell lines (51). In NCI-H2081 SCLC cells, $m i R-138$ reduced cell growth and inhibited cellcycle progression (51). Histone $\mathrm{H} 2 \mathrm{~A}$ variant $\mathrm{X}(\mathrm{H} 2 \mathrm{AX})$ was identified as a target of miR-138 (51). H2AX knockdown achieved a similar effect as observed for $m i R-138$ overexpression, whilst its induction abolished miR-138mediated SCLC cell growth and inhibition of cell-cycle progression (51). Expression of $m i R-138$ was shown to confer SCLC cells with greater DNA-repair capacity and reduced 


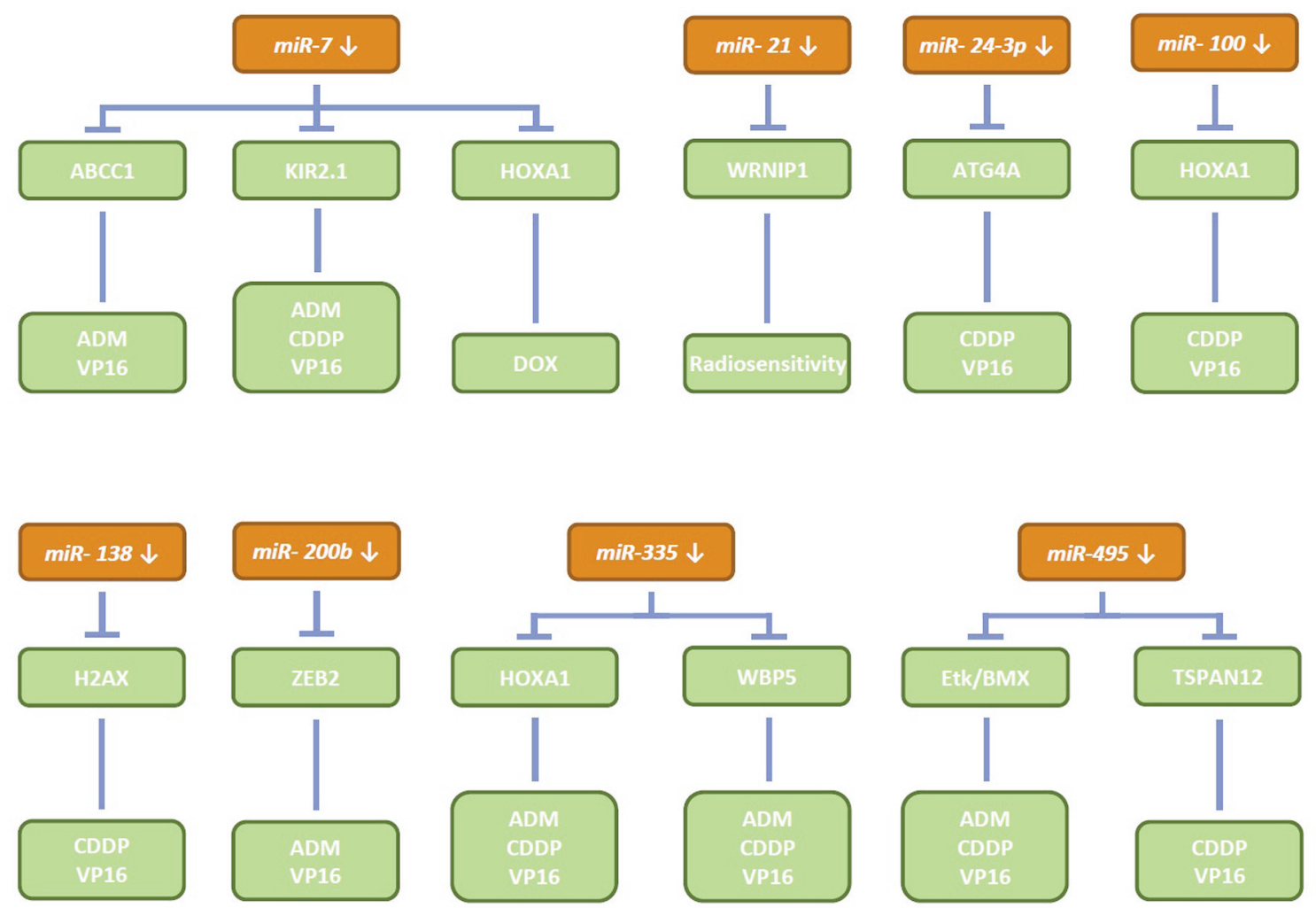

Figure 1. miRs involved in chemo- and radio-resistance of small-cell lung cancer (SCLC) cells. Downward arrows indicate down-regulation of miRs in SCLC in comparison to controls. ABCC1: ATB binding cassette subfamily C member; ADM: Adriamycin; ATG4A: autophagy-related protein 4; BMX: cytoplasmic tyrosine kinase BMX; CDDP: cisplatin; ETK: non-receptor tyrosine kinase Etk; H2AX: histone H2AX; HOXA1: homebox protein HOXA1; KIR2.1: inward rectifier ion channel 2.1; PARP1: poly (ADP ribose)-polymerase 1; TSPAN 12: tetraspanin 12; VP16: etoposide; WBP5: ww domain-binding protein 1; WRNIP1: ATPase WRNIP1; ZEB2: zinc finger E-box-binding homeobox 2.

their resistance to chemotherapeutic agents (51). $\mathrm{H} 2 \mathrm{AX}$ is involved in double-stranded DNA repair, chromatin remodeling and contributes to nucleosome formation (52-55).

miR-200b. miR-200b (Figure 1) targets zinc finger E-box homeobox2 (ZEB2), which correlated with poor pathologic stage and shorter survival (35). ZEB2 was found to be expressed in $23.5 \%(16 / 68)$ of cases of SCLC (56). Inhibition of ZEB2 expression making use of small-interfering RNA (siRNA), sensitized SCLC-related cells to chemotherapeutic drugs by enhancing drug-induced apoptosis accompanied by S-phase arrest (56). ZEB2 is a transcription factor with eight zinc fingers and a homeodomain (57). ZEB2 has been identified as a regulator of nervous system development (58, 59). In cancer, ZEB2 plays an instrumental role in epithelial mesenchymal transition (EMT), cancer-stem cell traits, apoptosis, survival, tumor recurrence and metastasis (60).

$m i R-335$. $m i R-335$ (Figure 1) was found to target WW domain-binding protein 5 (WBP5), expression of which was 10-fold increased in H69AR compared to H69 SCLC cells. WBP5 induced multidrug resistance by promoting cell proliferation and inhibiting apoptosis in H69AR cells (61). Expression of WBP5 was associated with shorter survival in patients with SCLC (61). WW binding domains are typically 35-40 amino acids in length and can interact with a variety of different peptide ligands, including motifs with core proline-rich sequences (62). WBP5 was shown to be involved in multidrug resistance of SCLC through the Hippo pathway [WBP5-tyrosine kinase ABL-mammalian Ste-20like kinase (MST2)-yes-associated protein1 (YAP1)] pathway (61). WBP5 can induce nuclear accumulation of YAP1, a transcription factor which induces genes involved in development and survival (63). Inhibition of YAP1 by verteporfin was shown to blunt multidrug resistance in H69AR cells (61). WBP5 can bind to ABL, an upstream activator of ser-thr kinase MST2 of the Hippo pathway $(64,65)$. It was shown that WBP5 promotes tumor growth and resistance of $\mathrm{H} 69$ cells to adriamycin and cisplatin in nude mice (61). 


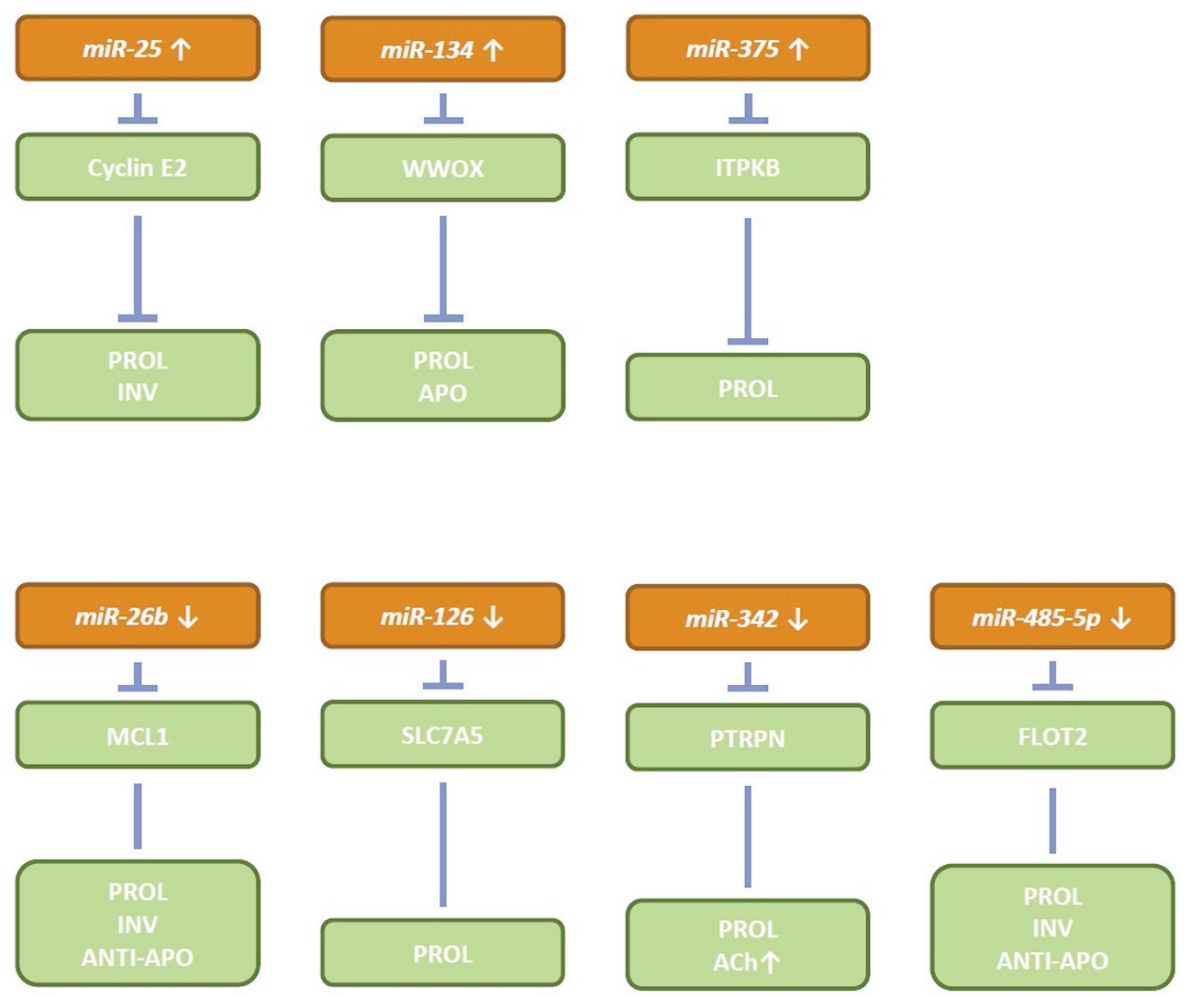

Figure 2. miRs Up-and down-regulated in small-cell lung cancer with in vitro activity. Upward arrows indicate increased expression and downward arrows point to decreased expression of the corresponding miRs in comparison to control tissues. ACh: Acetyl-choline; APO: apoptosis; FLOT2: flotillin 2; PTPRN: protein tyrosine phosphatase receptor type N; INV: invasion; ITPKB: inositol-triphosphate-3 kinase B; MCL1: myeloid cell differentiation protein 1; PROL: proliferation; SLC7A5: solute carrier family 7A5; WWOX: WW containing oxidoreductase.

$m i R-335$ was also down-regulated in SCLC cell lines H69AR and H446DDP (66). Overexpression of miR-335 inhibited migration of H69AR and H446DDP cells in vitro and their tumor growth in vivo, whereas its inhibition resulted in opposite effects (66). PARP1 was identified as a direct target of miR-335 (66). Chemoradiosensitiviy of SCLC cells was increased by down-regulation of $P A R P I$ and nuclear factor $\mathrm{kB}$ (66). Down-regulation of $m i R-335$ resulted in resistance to adriamycin, cisplatin and etoposide in SCLC cell lines H69AR and H446DDP (66). PARP1 detects single-strand DNA breaks and recruits other enzymes involved in DNA repair $(67,68)$.

miR-495. miR-495 (Figure 1) was down-regulated in SCLC and inhibited chemoresistance by targeting endothelial tyrosine kinase/bone marrow X kinase (ETK/BMX) (69) and tetraspanin 12 (TSPN12) (70). Functional assays were performed in SCLC cell lines NCI-H446, NCI-H69 and their multidrug-resistant derivatives H446AR and H69AR (69, 70). miR-495 was expressed at a lower level in SCLC compared to normal lung tissues $(69,70)$.

$m i R-495$ inhibited apoptosis induced by chemotherapeutic agents such as adriamycin, cisplatin and etoposide by targeting ETK/BMX (69). In nude mice, antagomirs directed against $m i R-495$ induced rapid growth of xenografts derived from H69 and H446 cells (69). Down-regulation of miR-495 promoted proliferation, migration invasion and tumor growth of H446 and H69 SCLC in vitro and in vivo (69). ETK/BMX has been shown to mediate drug resistance in SCLC (71), to regulate the cytoskeleton and migration (72), and to up-regulate vascular endothelial growth factor (73). ETK/BMX has also been identified as a mediator of resistance in acute myeloid leukemia (74) and as a regulator of multiple tyrosine kinases in hormone-refractory prostate cancer (75).

miR-495 was also found to target TSPAN12, which is related to resistance to cisplatin and etoposide (60). TSPAN12 promoted proliferation, migration and tumor growth in drugresistant SCLC cells H466AR and H69AR (60). TSPAN12 belongs to the tetraspanin family of transmembrane receptors characterized by four transmembrane domains and two extracellular loops (76). Tetraspanins are involved in signaling platforms by forming tetrapanin-enriched microdomains (77). Tetraspanins can mediate tumor-promoting but also metastasisinhibitory processes (78-80). 


\section{miRs Up-regulated in SCLC With Activity in Preclinical In Vitro Systems}

$m i R-25 . m i R-25$ (Figure 2) was up-regulated in SCLC cell lines and tissues (81). Down-regulation of $m i R$ - 25 induced cell-cycle arrest and inhibited invasive capability of H510 SCLC cells (81). Overexpression of $m i R-25$ reversed the effect of $m i R-25$ down-regulation in $\mathrm{H} 510$ cells (81). $m i R$ 25 acted as an oncogene in SCLC cell lines (81). Cyclin E2 has been identified as a direct target of $m i R-25$. These findings seem to be counterintuitive since cyclin $\mathrm{E}$ has been identified as a regulator of S-phase activity by binding to and activating cyclin-dependent kinase 2 and by phosphorylation of pocket proteins initiating a cascade of events that leads to the expression of S-phase-specific genes $(82,83)$. A role of cyclin E in DNA replication, control of genomic stability and regulation of the centrosome cycle has also been reported $(82,83)$. Cyclin E2 is aberrantly expressed in many types of tumors and is increased in cancer-derived cell lines (84). Overexpression of cyclin $\mathrm{E}$ in transgenic mice was shown to induce cancer by acting as a dominant oncogene (85). Due to its role in proliferation and apoptosis, cyclin E2 may be an important target for cancer therapy (86). However, it was shown that cyclin $\mathrm{E}$ is dispensable for the development of higher eukaryotes and for the division of eukaryotic cells (85). In any case, down-regulation of cyclin E2 in SCLC as reported in (81) might activate a novel tumor-promoting pathway which has to be resolved in further detail.

$m i R-134$. In H69 SCLC cells, miR-134 (Figure 2) promoted growth, inhibited apoptosis and activated the extracellular signal-regulated kinase 1/2 (ERK1/2) pathway (87). WW domain-containing oxidoreductase (WWOX) has been identified as a direct target of $m i R-134$ (87). WWOX has two WW domains responsible for protein-protein interactions and a short dehydrogenase/reductase domain which catalyses conversion of low-molecular-weight ligands, most likely steroids (88). Ectopic expression of WWOX inhibited anchorage-dependent growth of MDA-MB-435 and T47D breast cancer cells and attenuates tumorigenicity of MDAMB-435 cells in vivo (89). In lung cancer, WWOX gene restoration prevented tumor growth in vitro and in vivo (89). WWOX localizes to the Golgi apparatus and behaves as a tumor suppressor (90). WWOX is frequently down-regulated in human tumors $(91,92)$.

$m i R-375 . m i R-375$ (Figure 2) was found to be up-regulated in lung adenocarcinoma and SCLC, and down-regulated in lung squamous cell carcinoma (93). miR-375 promoted proliferation of NCI-H82 SCLC cells (93). Inositoltriphosphate-3 kinase B (ITPKB) was identified as a target of miR-375 (93). ITPKB regulates inositol phosphate metabolism by phosphorylation of second messenger inositol-1,4,5 triphosphate $(94,95)$. ITPKB is associated with the $\mathrm{Ca}$ signaling pathway and is enriched at actin filaments and invaginations of the nuclear envelope (96). ITPKB also regulates immune functions and is required for B- and T-cell development (96). The role of $m i R-375$ and down-regulation of ITPKB in SCLC remains to be investigated in further detail.

\section{miRs Down-regulated in SCLC With Activity in Preclinical In Vitro Systems}

$m i R-26 a$. Low level expression of $m i R-26 a$ (Figure 2) was detected in SCLC cell lines NCI-H196, NCI-H466 and NCIH1688 in comparison to MRC5 non-transformed control cells (97). Transfection of these cell lines with a $m i R-26 a$ mimic suppressed proliferation, migration and colony formation (97). Myeloid cell leukemia protein 1 (MCL1) has been identified as a target of $m i R-26 a$ (97). MCL1 is a member of the BCL2 family and plays a role in inhibition of apoptosis induced by tumor necrosis factor-related apoptosisinducing ligand $(98,99)$. Inhibition of MCL1 with small molecules has been pursued in several types of cancer, such as myeloma, follicular lymphoma and advanced SCLC in advanced clinical studies (100-102). MCL1 inhibition has been shown to be effective against a subset of SCLCs with high MCL1 and low B-cell lymphoma-extra large (BCL-XL) expression (101).

miR-126. miR-126 (Figure 2) inhibited proliferation of H69 SCLC cells by causing delay in the $\mathrm{G}_{1}$ phase of the cellcycle (102). miR-126 has been identified as a direct target of solute carrier family 7, member 5 (SLC7A5) (102). Suppression of SLC7A5 by RNAi delayed SCLC cells in the $G_{1}$ phase (103). SLC7A5 is part of cluster of differentiation 98 (CD98), and also referred to as large neutral amino acid transporter 1 . The other component of CD98 is the CD98 heavy subunit protein encoded by the SCL3A2 gene. CD98 preferentially transports branched chain and aromatic amino acids and is overexpressed in several types of cancer (103-105). SCL7A5 can activate mechanistic target of rapamycin (mTOR), which phosphorylates p70S6 kinase and eukaryotic translation factor 4E-binding protein 1 (4EBP1), resulting in production of growth-promoting proteins (106). mTOR is activated in a large percentage of SCLCs and genetic alterations in the phosphatidylinositol-4,5-bisphosphate 3-kinase/AKT serine/threonine kinase $1 / \mathrm{mTOR}$ pathway have been identified in $36 \%$ of patients with SCLC (107).

$m i R$-342. Protein tyrosine phosphatase receptor type $\mathrm{N}$ (PTPRN), also known as islet antigen 2 (IA-2), was identified as a target of $m i R$-342 (Figure 2) in SCLC cell lines NCI-H82 and NCI-345 (108). Down-regulation of PTPRN by siRNA suppressed SCLC growth as well as cell acetyl choline (ACh) 
content and secretion (109). ACh rescued the inhibitory effects of PTPRN siRNA and of $m i R-342$ mimic on SCLC proliferation (109). ACh is an autocrine growth factor which facilitates SCLC growth (109). PTPRN is a transmembrane tyrosine receptor phosphatase and has an important role in secretion of hormones and neurotransmitters in SCLC cell lines, such as follicle-stimulating hormone, insulin, luteinizing hormone, dopamine, renin and norepinephrine $(110,111)$. PTPRN is highly expressed in tumors and cell lines of neuro-endocrine origin (112). It also has been identified as an auto-antigen that is reactive with sera of patients with insulin-dependent diabetes mellitus (112).

miR-485-5p. miR-485-5p (Figure 2) was reduced in SCLC tissues compared to adjacent normal tissues (113). miR-485$5 \mathrm{p}$ inhibited proliferation, migration and invasion of NCIH466 and NCI-485-5p SCLC cell lines (113). Flotillin 2 (FlOT2) has been identified as a target of miR-485-5p (113). FLOT2 was found to be up-regulated in SCLC tissues and correlated with worse prognosis (113). FLOT1 and -2 are lipid-raft marker proteins which assemble into heterotetramers, forming molecular scaffolds to regulate clustering at the plasma membrane $(114,115)$. They are involved in signal transduction, nerve regeneration, endocytosis and lymphocyte activation $(114,115)$. Up-regulation of FLOT2 is related to lymph node metastasis and poor prognosis in patients with solid tumors (116).

\section{Dysregulated miRs With Activity in Preclinical In Vivo Models of SCLC}

\section{Up-regulated miRs \\ $m i R-665$. Inhibition of miR-665 (Figure 3) attenuated proliferation, invasion and migration of NCI-H446 SCLC cells (117). In vivo, inhibition of miR-665 led to attenuation of tumor growth (117). Lethal giant larvae protein homolog-1 (LLGL1) was identified as a target of miR-665 (117). LLGL1 is part of the cytoskeletal network and is associated with non- muscle myosin II heavy chain (117). Overexpression of LLGL1 inhibited proliferation and migration, and increased cellular adhesion and apoptosis $(118,119)$. Loss of LLGL1 reduced cellular adhesion and dissemination in colorectal cancer, melanoma and gastric cancer; its reduced expression has been noted in lung squamous cell carcinoma (120-123).}

\section{Down-regulated miRs}

miR-216a-5p. miR-216a-5p (Figure 3) reduced proliferation and migration of H69 SCLC cells (124). miR-216a-5p targeted BCL2 and modulated BCL2-like protein (BAX) and BCL2 antagonist of cell death (BAD) (124). In vivo inhibition of $m i R-216 a-5 p$ promoted tumor growth of H69derived xenografts in mice, whereas a $m i R-216$ mimic inhibited it (124). BCL2 is an anti-apoptotic protein which is expressed in SCLC $(125,126)$. BCL2 inhibitor venetoclax was shown to be active in preclinical SCLC-related in vitro and in vivo systems with high BCL2 expression (127). Venetoclax is approved for chronic lymphocytic leukemia and small lymphocytic leukemia, and is also part of a combination therapy for acute myeloid leukemia (128). Currently clinical studies of treatment of relapsed or refractory SCLC with oral venetoclax in combination with irinotecan and venetoclax in combination with atezolizumab are underway (NCI04543916).

$m i R-335$. Investigations into the role of $m i R-335$ (Figure 3 ) were performed with SCLC cells lines SBC-3 and SBC-5. The latter gives rise to bone metastasis in immuno-deficient mouse models, SBC-3 does not. Reduced expression of $m i R-335$ in SBC-5 in comparison to SBC-3 cells was observed (129). Overexpression of $m i R-335$ in transfected SBC-5 cells reduced proliferation, migration and colony formation. Skeletal lesions from miR-335-transfected SBC-5 cells were not observed in immunodeficient mice (129). Insulin-like growth factor receptor 1 (IGF-1R) and osteoblast receptor activator of nuclear $\mathrm{kB}$ ligand (RANKL) were identified as targets for $m i R-335$ (129). IGF-1R promotes proliferation, invasion, migration and inhibits apoptosis of tumor cells (130). IGF-1R knock-out mice exhibit reduced bone metastasis of breast cancer xenografts (131). Prerequisite for osteolytic metastases is the activation of osteoclasts. Osteoblasts secrete RANKL which interacts with osteoclast precursors displaying RANK receptor on their surface, resulting in their maturation into functional osteoclasts. Osteoblasts also produce osteoprotegerin, a soluble decoy receptor which can block RANK/RANKL signaling (132-134). miR-335 inhibits IGF-1R and RANKL, two validated mediators of bone metastasis.

$m i R-450$. Down-regulation of $m i R-450$ (Figure 3 ) correlated with reduced survival in patients with SCLC (135). miR-450 inhibited proliferation and invasion of H510A SCLC cells and growth as xenografts implanted into immunodeficient mice (135). Interferon regulatory factor 2 (IRF2) was identified as a target of $m i R-450$ (135). Overexpression of IRF2 in H510A cells abrogated the inhibitory effects of $m i R$ 450 (136). IRF2 is a member of IRF protein family which possess an $\mathrm{N}$-terminal DNA binding domain characterized by five well-conserved tryptophan-rich repeats recognizing IFNstimulated response elements and a $C$-terminal region which mediates interactions with family members, transcription factors and co-factors conferring specific activities on each IRF $(136,137)$. IRF2 acts as an oncogene and is involved in regulation of histone 4 gene transcription $(138,139)$. Overexpression of IRF2 promotea the growth of pancreatic cancer cells (140). In colorectal cancer, IRF2 has been identified as a driver of immune suppression and immune therapy resistance (141). 




Figure 3. miRs Up-and down-regulated with activity in preclinical small-cell lung cancer-related in vivo models. Upward arrows: Upregulated miRs; downward arrows: down-regulated miRs. APO: Apoptosis; BCL2: BCL2 apoptosis regulator; BM: bone metastasis; EMT: epithelial-mesenchymal transition; IGF-1R: insulin-like growth factor receptor 1; INV: invasion; IRF2: interferon regulatory factor 2; LLGL1: lethal giant larvae protein homolog 1; PROL: proliferation; RANK: receptor activator of $N F K B$ ligand; RANKL: RANK ligand; TGF $\beta 1$ : transforming growth factor $\beta 1$; TS: tumor suppressor.

miR-886-3p. $m i R-886-3$ p (Figure 3) was down-regulated in SCLC (141). In NCI-H446 and NCI-H1688, overexpression of $m i R-886-3 \mathrm{p}$ induced mesenchymal-epithelial transition, a change in cellular phenotype from spindle shape to round shape (141). Transforming growth factor $\beta 1$ (TGF $\beta 1$ ) has been identified as a target of $m i R-886-3 p$ (141). $m i R-886$ $3 p$-mediated mesenchymal epithelial transition was induced by suppression of TGF $\beta$ (141). Intratumoral injection of a $m i R-886-3 p$ conjugate to cholesterol resulted in necrosis of tumor tissue and suppression of intramuscular invasion (141). Suppression of lung cancer xenograft growth of NCIH446 cells was observed after systemic delivery of a cholesterol conjugated $m i R-886-3 \mathrm{p}$ mimic after tail vein injection of tumor cells. Targeting EMT by either inhibition of TGF $\beta$ or by administration of $m i R-886-3 p$ may be a concept for treatment of SCLC which has to be validated in further detail. EMT is a basic principle of tumor progression (142-144).

\section{Conclusion}

We identified miRs which affect chemoresistance and radioresistance, as well as in vitro and in vivo properties of SCLC cell lines. Up-regulated miRs are candidates for inhibition or reconstitution of the corresponding targets. Down-regulated miRs are candidates for reconstitution therapy or inhibition of the corresponding targets with small molecules or antibody-related entities.

Up-regulated miRs can be inhibited with miR antagonists, which are single-stranded RNAs composed of 12-25 nucleotides complementary to the corresponding mRNA or with RNA sponges $(145,146)$. The latter are composed of multiple miR-binding sites competing with binding of miRs to corresponding mRNA $(145,146)$. In the case of downregulated miRs, reconstitution therapy is the indicated therapeutic intervention $(147,148)$ or re-expression of the corresponding targets, an approach which faces druggability issues due to nonspecific interactions.

Eight down-regulated miRs were found to mediate chemo/radioresistance (Figure 1). They are candidates for reconstitution therapy. PARP1 (miR-335) can be inhibited by several approved small molecules and is a validated target $(35,36)$. ETK (BMX) (miR-495), TSPAN12 (miR-495) and KIR2.1 (miR-7) are druggable with small molecules or antibody-derived entities. However, the role of the identified miRs in resistance of relapsed SCLC needs to be validated in more detail.

Three up-regulated and four down-regulated miRs affecting proliferation, invasion and apoptosis of SCLC cell lines in vitro were identified (Figure 2). MCL1, which is targeted by $m i R-26 a$, seems to be a promising target. MCL1 inhibition has been shown to be effective in a subset of preclinical SCLC-related in vitro models with high MCL1 and low BCL-xL expression (101). PTPRN (miR-342) and SCL7A5 (miR-126) are druggable targets and the corresponding miRs are candidates for miR-inhibitory agents. However, more target validation experiments are necessary to resolve the relevance of the latter targets.

Furthermore, one up-regulated and four down-regulated miRs with efficacy in preclinical SCLC-related in vivo models were identified (Figure 3). The down-regulated miRs are candidates for substitution therapy. BCL2 ( $m i R-216-5 \mathrm{p})$ is inhibited by venetoclax and it has been shown that venetoclax is effective in preclinical in vivo models with high BCL2 expression (127). miR-335 targets IGF-1R and RANKL, which mediate proliferation, invasion and bone metastasis of SCLC and both represent druggable targets (130, 132). miR-886-3p inhibits TGF $\beta 1$, a possible target for interfering with EMT $(143,144)$. For these miRs and corresponding targets, more target validation experiments in non-small-cell lung carcinoma-related systems are necessary in order to substantiate their role in SCLC. 
Regarding miR-based therapy, many technical hurdles which are not discussed in detail here have been identified. Issues are targeting of miRs to tumor cells, efficacy of intracellular escape, removal by the reticulo-endothelial system, excretion by the kidneys, pharmaco-kinetic and pharmaco-dynamic issues, immunogenicity, toxicity and cytokine-release syndrome (149-154). Recently, the field has experienced several set-backs, mainly due to toxicity issues (155). It remains to be seen whether miRs are tools for further target identification and whether miR-based therapy is a viable strategy for treatment of SCLC.

\section{Conflicts of Interest}

AN is and UHW was an employee of Roche.

\section{Authors' Contributions}

AN and UHW jointly designed and prepared the article.

\section{References}

1 Gazdar AF, Bunn PA and Minna JD: Small-cell lung cancer: what we know, what we need to know and the path forward. Nat Rev Cancer 17(12): 725-737, 2017. PMID: 29077690. DOI: $10.1038 /$ nrc. 2017.87

2 Pietanza MC, Byers LA, Minna JD and Rudin CM: Small cell lung cancer: will recent progress lead to improved outcomes? Clin Cancer Res 21(10): 2244-2255, 2015. PMID: 25979931. DOI: 10.1158/1078-0432.CCR-14-2958

3 Farago AF, Drapkin BJ, Lopez-Vilarino de Ramos JA, Galmarini CM, Núñez R, Kahatt C and Paz-Ares L: ATLANTIS: a Phase III study of lurbinectedin/doxorubicin versus topotecan or cyclophosphamide/doxorubicin/vincristine in patients with smallcell lung cancer who have failed one prior platinum-containing line. Future Oncol 15(3): 231-239, 2019. PMID: 30362375. DOI: 10.2217/fon-2018-0597

4 Gazdar AF and Minna JD: Small cell lung cancers made from scratch. J Exp Med 216(3): 476-478, 2019. PMID: 30760489. DOI: $10.1084 /$ jem.20182216

5 Iams WT, Porter J and Horn L: Immunotherapeutic approaches for small-cell lung cancer. Nat Rev Clin Oncol 17(5): 300-312, 2020. PMID: 32055013. DOI: 10.1038/s41571-019-0316-z

6 Rudin CM, Poirier JT, Byers LA, Dive C, Dowlati A, George J, Heymach JV, Johnson JE, Lehman JM, MacPherson D, Massion PP, Minna JD, Oliver TG, Quaranta V, Sage J, Thomas RK, Vakoc CR and Gazdar AF: Molecular subtypes of small cell lung cancer: a synthesis of human and mouse model data. Nat Rev Cancer 19(5): 289-297, 2019. PMID: 30926931. DOI: 10.1038/s41568-019-0133-9

7 Dawkins JBN and Webster RM: The small-cell lung cancer drug market. Nat Rev Drug Discov 19(8): 507-508, 2020. PMID: 32235872. DOI: 10.1038/d41573-020-00057-5

8 Bartel DP: Metazoan MicroRNAs. Cell 173(1): 20-51, 2018. PMID: 29570994. DOI: 10.1016/j.cell.2018.03.006

$9 \mathrm{Li} \mathrm{Z}$ and Rana TM: Therapeutic targeting of microRNAs: current status and future challenges. Nat Rev Drug Discov 13(8): 622638, 2014. PMID: 25011539. DOI: 10.1038/nrd4359
10 Rupaimoole R and Slack FJ: MicroRNA therapeutics: towards a new era for the management of cancer and other diseases. Nat Rev Drug Discov 16(3): 203-222, 2017. PMID: 28209991. DOI: 10.1038/nrd.2016.246

11 Peter ME: Targeting of mRNAs by multiple miRNAs: the next step. Oncogene 29(15): 2161-2164, 2010. PMID: 20190803. DOI: 10.1038/onc.2010.59

12 Garzon R, Calin GA and Croce CM: MicroRNAs in Cancer. Annu Rev Med 60: 167-179, 2009. PMID: 19630570. DOI: 10.1146/annurev.med.59.053006.104707

13 Calin GA, Cimmino A, Fabbri M, Ferracin M, Wojcik SE, Shimizu M, Taccioli C, Zanesi N, Garzon R, Aqeilan RI, Alder H, Volinia S, Rassenti L, Liu X, Liu CG, Kipps TJ, Negrini M and Croce CM: MiR-15a and miR-16-1 cluster functions in human leukemia. Proc Natl Acad Sci USA 105(13): 5166-5171, 2008. PMID: 18362358. DOI: 10.1073/pnas.0800121105

14 Calin GA, Dumitru CD, Shimizu M, Bichi R, Zupo S, Noch E, Aldler H, Rattan S, Keating M, Rai K, Rassenti L, Kipps T, Negrini M, Bullrich F and Croce CM: Frequent deletions and down-regulation of micro- RNA genes miR15 and miR16 at 13 q14 in chronic lymphocytic leukemia. Proc Natl Acad Sci USA 99(24): 15524-15529, 2002. PMID: 12434020. DOI: 10.1073/pnas.242606799

15 Callegari E, Elamin BK, Giannone F, Milazzo M, Altavilla G, Fornari F, Giacomelli L, D'Abundo L, Ferracin M, Bassi C, Zagatti B, Corrà F, Miotto E, Lupini L, Bolondi L, Gramantieri L, Croce CM, Sabbioni S and Negrini M: Liver tumorigenicity promoted by microRNA-221 in a mouse transgenic model. Hepatology 56(3): 1025-1033, 2012. PMID: 22473819. DOI: 10.1002/hep.25747

16 Ali Syeda Z, Langden SSS, Munkhzul C, Lee M and Song SJ: Regulatory mechanism of MicroRNA expression in cancer. Int $\mathrm{J}$ Mol Sci 21(5): 1723, 2020. PMID: 32138313. DOI: 10.3390/ijms 21051723

17 Weidle UH, Schmid D, Birzele F and Brinkmann U: MicroRNAs involved in metastasis of hepatocellular carcinoma: Target candidates, functionality and efficacy in animal models and prognostic relevance. Cancer Genomics Proteomics 17(1): 1-21, 2020. PMID: 31882547 . DOI: $10.21873 / \mathrm{cgp} .20163$

18 Weidle UH, Birzele F and Nopora A: Pancreatic ductal adenocarcinoma: MicroRNAs affecting tumor growth and metastasis in preclinical in vivo models. Cancer Genomics Proteomics 16(6): 451-464, 2019. PMID: 31659100. DOI: $10.21873 / \operatorname{cgp} .20149$

19 Weidle UH, Birzele F and Nopora A: MicroRNAs as potential targets for therapeutic intervention with metastasis of non-small cell lung cancer. Cancer Genomics Proteomics 16(2): 99-119, 2019. PMID: 30850362. DOI: $10.21873 / \operatorname{cgp} .20116$

20 Weidle UH, Dickopf S, Hintermair C, Kollmorgen G, Birzele F and Brinkmann U: The role of micro RNAs in breast cancer metastasis: Preclinical validation and potential therapeutic targets. Cancer Genomics Proteomics 15(1): 17-39, 2018. PMID: 29275360. DOI: $10.21873 / \mathrm{cgp} .20062$

21 Weidle UH, Epp A, Birzele F and Brinkmann U: The functional role of prostate cancer metastasis-related Micro-RNAs. Cancer Genomics Proteomics 16(1): 1-19, 2019. PMID: 30587496. DOI: $10.21873 / \operatorname{cgp} .20108$

22 Liu H, Wu X, Huang J, Peng J and Guo L: miR-7 modulates chemoresistance of small cell lung cancer by repressing MRP1/ABCC1. Int J Exp Pathol 96(4): 240-247, 2015. PMID: 26108539. DOI: $10.1111 /$ iep.12131 
23 Liu H, Huang J, Peng J, Wu X, Zhang Y, Zhu W and Guo L: Upregulation of the inwardly rectifying potassium channel Kir2.1 (KCNJ2) modulates multidrug resistance of small-cell lung cancer under the regulation of miR-7 and the Ras/MAPK pathway. Mol Cancer 14: 59, 2015. PMID: 25880778. DOI: 10.1186/s12943015-0298-0

24 Lai J, Yang H, Zhu Y, Ruan M, Huang Y and Zhang Q: MiR-7$5 p$-mediated downregulation of PARP1 impacts DNA homologous recombination repair and resistance to doxorubicin in small cell lung cancer. BMC Cancer 19(1): 602, 2019. PMID: 31215481. DOI: 10.1186/s12885-019-5798-7

25 Zaman GJ, Versantvoort CH, Smit JJ, Eijdems EW, de Haas M, Smith AJ, Broxterman HJ, Mulder NH, de Vries EG and Baas F: Analysis of the expression of MRP, the gene for a new putative transmembrane drug transporter, in human multidrug resistant lung cancer cell lines. Cancer Res 53(8): 1747-1750, 1993. PMID: 8467491.

26 Robey RW, Pluchino KM, Hall MD, Fojo AT, Bates SE and Gottesman MM: Revisiting the role of $\mathrm{ABC}$ transporters in multidrug-resistant cancer. Nat Rev Cancer 18(7): 452-464, 2018. PMID: 29643473. DOI: 10.1038/s41568-018-0005-8

27 Hsia TC, Lin CC, Wang JJ, Ho ST and Kao A: Relationship between chemotherapy response of small cell lung cancer and P-glycoprotein or multidrug resistance-related protein expression. Lung 180(3): 173-179, 2002. PMID: 12177731. DOI: $10.1007 / \mathrm{s} 004080000091$

28 Kuo TH, Liu FY, Chuang CY, Wu HS, Wang JJ and Kao A: To predict response chemotherapy using technetium- $99 \mathrm{~m}$ tetrofosmin chest images in patients with untreated small cell lung cancer and compare with p-glycoprotein, multidrug resistance related protein1 , and lung resistance-related protein expression. Nucl Med Biol 30(6): 627-632, 2003. PMID: 12900288. DOI: 10.1016/s09698051(03)00058-1

29 Mirski SE, Gerlach JH and Cole SP: Multidrug resistance in a human small cell lung cancer cell line selected in adriamycin. Cancer Res 47(10): 2594-2598, 1987. PMID: 2436751.

30 Raab-Graham KF, Radeke CM and Vandenberg CA: Molecular cloning and expression of a human heart inward rectifier potassium channel. Neuroreport 5(18): 2501-2505, 1994. PMID: 7696590. DOI: 10.1097/00001756-199412000-00024

31 Hibino H, Inanobe A, Furutani K, Murakami S, Findlay I and Kurachi Y: Inwardly rectifying potassium channels: their structure, function, and physiological roles. Physiol Rev 90(1): 291-366, 2010. PMID: 20086079. DOI: 10.1152/physrev.00021.2009

32 Pancrazio JJ, Viglione MP, Tabbara IA and Kim YI: Voltagedependent ion channels in small-cell lung cancer cells. Cancer Res 49(21): 5901-5906, 1989. PMID: 2477149

33 Giovannardi S, Forlani G, Balestrini M, Bossi E, Tonini R, Sturani E, Peres A and Zippel R: Modulation of the inward rectifier potassium channel IRK1 by the Ras signaling pathway. J Biol Chem 277(14): 12158-12163, 2002. PMID: 11809752. DOI: $10.1074 / j b c . M 110466200$

34 Tsoukalas N, Aravantinou-Fatorou E, Baxevanos P, Tolia M, Tsapakidis K, Galanopoulos M, Liontos M and Kyrgias G: Advanced small cell lung cancer (SCLC): new challenges and new expectations. Ann Transl Med 6(8): 145, 2018. PMID: 29862234. DOI: 10.21037/atm.2018.03.31

35 Ray Chaudhuri A and Nussenzweig A: The multifaceted roles of PARP1 in DNA repair and chromatin remodelling. Nat Rev Mol
Cell Biol 18(10): 610-621, 2017. PMID: 28676700. DOI: $10.1038 / \mathrm{nrm} .2017 .53$

36 Lord CJ, Tutt AN and Ashworth A: Synthetic lethality and cancer therapy: lessons learned from the development of PARP inhibitors. Annu Rev Med 66: 455-470, 2015. PMID: 25341009. DOI: 10.1146/annurev-med-050913-022545

37 Lord CJ and Ashworth A: PARP inhibitors: Synthetic lethality in the clinic. Science 355(6330): 1152-1158, 2017. PMID: 28302823. DOI: $10.1126 /$ science.aam7344

38 Slade D: PARP and PARG inhibitors in cancer treatment. Genes Dev 34(5-6): 360-394, 2020. PMID: 32029455. DOI: 10.1101/gad.334516.119

39 Jiang W, Han X, Wang J, Wang L, Xu Z, Wei Q, Zhang W and Wang H: miR-22 enhances the radiosensitivity of small-cell lung cancer by targeting the WRNIP1. J Cell Biochem 120(10): 1765017661, 2019. PMID: 31190355. DOI: 10.1002/jcb.29032

40 Kawabe Yi, Branzei D, Hayashi T, Suzuki H, Masuko T, Onoda F, Heo SJ, Ikeda H, Shimamoto A, Furuichi Y, Seki M and Enomoto T: A novel protein interacts with the Werner's syndrome gene product physically and functionally. J Biol Chem 276(23): 20364-20369, 2001. PMID: 11301316. DOI: 10.1074/jbc.C100035200

41 Kawabe Y, Seki M, Yoshimura A, Nishino K, Hayashi T, Takeuchi $\mathrm{T}$, Iguchi S, Kusa Y, Ohtsuki M, Tsuyama T, Imamura $\mathrm{O}$, Matsumoto T, Furuichi Y, Tada S and Enomoto T: Analyses of the interaction of WRNIP1 with Werner syndrome protein (WRN) in vitro and in the cell. DNA Repair (Amst) 5(7): 816-828, 2006. PMID: 16769258. DOI: 10.1016/j.dnarep.2006.04.006

42 Leuzzi G, Marabitti V, Pichierri P and Franchitto A: WRNIP1 protects stalled forks from degradation and promotes fork restart after replication stress. EMBO J 35(13): 1437-1451, 2016. PMID: 27242363. DOI: $10.15252 / \mathrm{embj} .201593265$

43 Levy JMM, Towers CG and Thorburn A: Targeting autophagy in cancer. Nat Rev Cancer 17(9): 528-542, 2017. PMID: 28751651. DOI: $10.1038 / \mathrm{nrc} .2017 .53$

44 Yang ZJ, Chee CE, Huang S and Sinicrope FA: The role of autophagy in cancer: therapeutic implications. Mol Cancer Ther 10(9): 1533-1541, 2011. PMID: 21878654. DOI: 10.1158/15357163.MCT-11-0047

45 Pan B, Chen Y, Song H, Xu Y, Wang R and Chen L: Mir-24-3p downregulation contributes to VP16-DDP resistance in small-cell lung cancer by targeting ATG4A. Oncotarget 6(1): 317-331, 2015. PMID: 25426560. DOI: 10.18632/oncotarget.2787

46 Amaravadi RK, Lippincott-Schwartz J, Yin XM, Weiss WA, Takebe N, Timmer W, DiPaola RS, Lotze MT and White E: Principles and current strategies for targeting autophagy for cancer treatment. Clin Cancer Res 17(4): 654-666, 2011. PMID: 21325294. DOI: $10.1158 / 1078-0432$.CCR-10-2634

47 Xiao F, Bai Y, Chen Z, Li Y, Luo L, Huang J, Yang J, Liao H and Guo L: Downregulation of HOXA1 gene affects small cell lung cancer cell survival and chemoresistance under the regulation of miR-100. Eur J Cancer 50(8): 1541-1554, 2014. PMID: 24559685. DOI: 10.1016/j.ejca.2014.01.024

48 Yuan C, Zhu X, Han Y, Song C, Liu C, Lu S, Zhang M, Yu F, Peng $\mathrm{Z}$ and Zhou C: Elevated HOXA1 expression correlates with accelerated tumor cell proliferation and poor prognosis in gastric cancer partly via cyclin D1. J Exp Clin Cancer Res 35: 15, 2016. PMID: 26791264. DOI: 10.1186/s13046-016-0294-2

49 Wang H, Liu G, Shen D, Ye H, Huang J, Jiao L and Sun Y: HOXA1 enhances the cell proliferation, invasion and metastasis 
of prostate cancer cells. Oncol Rep 34(3): 1203-1210, 2015. PMID: 26135141. DOI: 10.3892/or.2015.4085

50 Zha TZ, Hu BS, Yu HF, Tan YF, Zhang Y and Zhang K: Overexpression of HOXA1 correlates with poor prognosis in patients with hepatocellular carcinoma. Tumour Biol 33(6): 21252134, 2012. PMID: 22864671. DOI: 10.1007/s13277-012-0472-6

51 Yang H, Luo J, Liu Z, Zhou R and Luo H: MicroRNA-138 regulates DNA damage response in small cell lung cancer cells by directly targeting H2AX. Cancer Invest 33(4): 126-136, 2015. PMID: 25699650. DOI: 10.3109/07357907.2015.1006329

52 Matthaios D, Hountis P, Karakitsos P, Bouros D and Kakolyris S: $\mathrm{H} 2 \mathrm{AX}$ a promising biomarker for lung cancer: a review. Cancer Invest 31(9): 582-599, 2013. PMID: 24164298. DOI: 10.3109/07357907.2013.849721

53 Kuo LJ and Yang LX: Gamma-H2AX - a novel biomarker for DNA double-strand breaks. In Vivo 22(3): 305-309, 2008. PMID: 18610740.

54 Podhorecka M, Skladanowski A and Bozko P: H2AX phosphorylation: Its role in DNA damage response and cancer therapy. J Nucleic Acids 2010: 920161, 2010. PMID: 20811597. DOI: $10.4061 / 2010 / 920161$

55 Ivashkevich A, Redon CE, Nakamura AJ, Martin RF and Martin OA: Use of the $\gamma$-H2AX assay to monitor DNA damage and repair in translational cancer research. Cancer Lett 327(1-2): 123133, 2012. PMID: 22198208. DOI: 10.1016/j.canlet.2011.12.025

56 Fang S, Zeng X, Zhu W, Tang R, Chao Y and Guo L: Zinc finger E-box-binding homeobox 2 (ZEB2) regulated by miR-200b contributes to multi-drug resistance of small cell lung cancer. Exp Mol Pathol 96(3): 438-444, 2014. PMID: 24769353. DOI: 10.1016/j.yexmp.2014.04.008

57 Bürglin TR and Affolter M: Homeodomain proteins: an update. Chromosoma 125(3): 497-521, 2016. PMID: 26464018. DOI: 10.1007/s00412-015-0543-8

58 Hegarty SV, Sullivan AM and O'Keeffe GW: Zeb2: A multifunctional regulator of nervous system development. Prog Neurobiol 132: 81-95, 2015. PMID: 26193487. DOI: 10.1016/j.pneurobio.2015.07.001

59 Epifanova E, Babaev A, Newman AG and Tarabykin V: Role of Zeb2/Sip1 in neuronal development. Brain Res 1705: 24-31, 2019. PMID: 30266271. DOI: 10.1016/j.brainres.2018.09.034

60 Fardi M, Alivand M, Baradaran B, Farshdousti Hagh M and Solali S: The crucial role of ZEB2: From development to epithelial-tomesenchymal transition and cancer complexity. J Cell Physiol : , 2019. PMID: 30773635 . DOI: 10.1002/jcp.28277

61 Tang R, Lei Y, Hu B, Yang J, Fang S, Wang Q, Li M and Guo L: WW domain binding protein 5 induces multidrug resistance of small cell lung cancer under the regulation of miR-335 through the Hippo pathway. Br J Cancer 115(2): 243-251, 2016. PMID: 27336605. DOI: $10.1038 /$ bjc.2016.186

62 Sudol M, Chen HI, Bougeret C, Einbond A and Bork P: Characterization of a novel protein-binding module-the WW domain. FEBS Lett 369(1): 67-71, 1995. PMID: 7641887. DOI: 10.1016/0014-5793(95)00550-s

63 Zanconato F, Cordenonsi M and Piccolo S: YAP/TAZ at the roots of cancer. Cancer Cell 29(6): 783-803, 2016. PMID: 27300434. DOI: $10.1016 /$ j.ccell.2016.05.005

64 Liu W, Wu J, Xiao L, Bai Y, Qu A, Zheng Z and Yuan Z: Regulation of neuronal cell death by c-Abl-Hippo/MST2 signaling pathway. PLoS One 7(5): e36562, 2012. PMID: 22590567. DOI: 10.1371/journal.pone.0036562
65 Harvey KF, Zhang X and Thomas DM: The Hippo pathway and human cancer. Nat Rev Cancer 13(4): 246-257, 2013. PMID: 23467301. DOI: $10.1038 / \mathrm{nrc} 3458$

66 Luo Y, Tong L, Meng H, Zhu W, Guo L, Wei T and Zhang J: MiR-335 regulates the chemo-radioresistance of small cell lung cancer cells by targeting PARP-1. Gene 600: 9-15, 2017. PMID: 27871924. DOI: $10.1016 /$ j.gene.2016.11.031

67 Sachdev E, Tabatabai R, Roy V, Rimel BJ and Mita MM: PARP Inhibition in Cancer: An Update on Clinical Development. Target Oncol 14(6): 657-679, 2019. PMID: 31625002. DOI: 10.1007/s11523-019-00680-2

68 O'Connor MJ: Targeting the DNA Damage Response in Cancer. Mol Cell 60(4): 547-560, 2015. PMID: 26590714. DOI: 10.1016/j.molcel.2015.10.040

69 Wei T, Zhu W, Fang S, Zeng X, Huang J, Yang J, Zhang J and Guo L: miR-495 promotes the chemoresistance of SCLC through the epithelial-mesenchymal transition via Etk/BMX. Am J Cancer Res 7(3): 628-646, 2017. PMID: 28401017.

70 Ye M, Wei T, Wang Q, Sun Y, Tang R, Guo L and Zhu W: TSPAN12 promotes chemoresistance and proliferation of SCLC under the regulation of miR-495. Biochem Biophys Res Commun 486(2): 349-356, 2017. PMID: 28302484. DOI: 10.1016/j.bbrc. 2017.03.044

71 Guo L, Zhou Y, Sun Y and Zhang F: Non-receptor tyrosine kinase Etk regulation of drug resistance in small-cell lung cancer. Eur $\mathrm{J}$ Cancer 46(3): 636-641, 2010. PMID: 20004564. DOI: 10.1016/j.ejca.2009.11.009

72 Abassi YA, Rehn M, Ekman N, Alitalo K and Vuori K: p130Cas Couples the tyrosine kinase Bmx/Etk with regulation of the actin cytoskeleton and cell migration. J Biol Chem 278(37): 35636-35643, 2003. PMID: 12832404. DOI: 10.1074/jbc.M306438200

73 Chau CH, Chen KY, Deng HT, Kim KJ, Hosoya K, Terasaki T, Shih HM and Ann DK: Coordinating Etk/Bmx activation and VEGF upregulation to promote cell survival and proliferation. Oncogene 21(57): 8817-8829, 2002. PMID: 12483534. DOI: 10.1038/sj.onc.1206032

74 van Oosterwijk JG, Buelow DR, Drenberg CD, Vasilyeva A, Li L, Shi L, Wang YD, Finkelstein D, Shurtleff SA, Janke LJ, Pounds S, Rubnitz JE, Inaba H, Pabla N and Baker SD: Hypoxiainduced upregulation of BMX kinase mediates therapeutic resistance in acute myeloid leukemia. J Clin Invest 128(1): 369380, 2018. PMID: 29227282. DOI: 10.1172/JCI91893

75 Chen S, Cai C, Sowalsky AG, Ye H, Ma F, Yuan X, Simon NI, Gray NS and Balk SP: BMX-mediated regulation of multiple tyrosine kinases contributes to castration resistance in prostate cancer. Cancer Res 78(18): 5203-5215, 2018. PMID: 30012673. DOI: $10.1158 / 0008-5472 . C A N-17-3615$

76 Serru V, Dessen P, Boucheix C and Rubinstein E: Sequence and expression of seven new tetraspans. Biochim Biophys Acta 1478(1): 159-163, 2000. PMID: 10719184. DOI: 10.1016/s01674838(00)00022-4

77 Yáñez-Mó M, Barreiro O, Gordon-Alonso M, Sala-Valdés M and Sánchez-Madrid F: Tetraspanin-enriched microdomains: a functional unit in cell plasma membranes. Trends Cell Biol 19(9): 434-446, 2009. PMID: 19709882. DOI: 10.1016/j.tcb.2009.06.004

78 Hemler ME: Tetraspanin proteins promote multiple cancer stages. Nat Rev Cancer 14(1): 49-60, 2014. PMID: 24505619. DOI: 10.1038/nrc3640 
79 Zöller M: Tetraspanins: push and pull in suppressing and promoting metastasis. Nat Rev Cancer 9(1): 40-55, 2009. PMID: 19078974. DOI: $10.1038 / \mathrm{nrc} 2543$

80 Sala-Valdés M, Ailane N, Greco C, Rubinstein E and Boucheix C: Targeting tetraspanins in cancer. Expert Opin Ther Targets 16(10): 985-997, 2012. PMID: 22880813. DOI: $10.1517 / 147282$ 22.2012 .712688

81 Zhao Z, Liu J, Wang C, Wang Y, Jiang $\mathrm{Y}$ and Guo M: MicroRNA-25 regulates small cell lung cancer cell development and cell cycle through cyclin E2. Int J Clin Exp Pathol 7(11): 7726-7734, 2014. PMID: 25550809.

82 Hwang HC and Clurman BE: Cyclin E in normal and neoplastic cell cycles. Oncogene 24(17): 2776-2786, 2005. PMID: 15838514. DOI: $10.1038 /$ sj.onc. 1208613

83 Santamaria D and Ortega S: Cyclins and CDKS in development and cancer: lessons from genetically modified mice. Front Biosci 11: 1164-1188, 2006. PMID: 16146805. DOI: 10.2741/1871

84 Gudas JM, Payton M, Thukral S, Chen E, Bass M, Robinson MO and Coats S: Cyclin E2, a novel G1 cyclin that binds Cdk2 and is aberrantly expressed in human cancers. Mol Cell Biol 19(1): 612-622, 1999. PMID: 9858585. DOI: 10.1128/MCB.19.1.612

85 Möröy T and Geisen C: Cyclin E. Int J Biochem Cell Biol 36(8): 1424-1439, 2004. PMID: 15147722. DOI: 10.1016/j.biocel. 2003.12.005

86 Mazumder S, DuPree EL and Almasan A: A dual role of cyclin E in cell proliferation and apoptosis may provide a target for cancer therapy. Curr Cancer Drug Targets 4(1): 65-75, 2004. PMID: 14965268. DOI: 10.2174/1568009043481669

87 Chen T, Gao F, Feng S, Yang T and Chen M: MicroRNA-134 regulates lung cancer cell $\mathrm{H} 69$ growth and apoptosis by targeting WWOX gene and suppressing the ERK1/2 signaling pathway. Biochem Biophys Res Commun 464(3): 748-754, 2015. PMID: 26166818. DOI: 10.1016/j.bbrc.2015.07.021

88 Pospiech K, Płuciennik E and Bednarek AK: WWOX Tumor suppressor gene in breast cancer, a historical perspective and future directions. Front Oncol 8: 345, 2018. PMID: 30211123. DOI: $10.3389 /$ fonc. 2018.00345

89 Bednarek AK, Keck-Waggoner CL, Daniel RL, Laflin KJ, Bergsagel PL, Kiguchi K, Brenner AJ and Aldaz CM: WWOX, the FRA16D gene, behaves as a suppressor of tumor growth. Cancer Res 61(22): 8068-8073, 2001. PMID: 11719429.

90 Fabbri M, Iliopoulos D, Trapasso F, Aqeilan RI, Cimmino A, Zanesi N, Yendamuri S, Han SY, Amadori D, Huebner K and Croce CM: WWOX gene restoration prevents lung cancer growth in vitro and in vivo. Proc Natl Acad Sci USA 102(43): 1561115616, 2005. PMID: 16223882. DOI: 10.1073/pnas.0505485102

91 Schrock MS and Huebner K: WWOX: a fragile tumor suppressor Exp Biol Med (Maywood) 240(3): 296-304, 2015. PMID: 25538133. DOI: $10.1177 / 1535370214561590$

92 Baryła I, Styczeń-Binkowska E and Bednarek AK: Alteration of WWOX in human cancer: a clinical view. Exp Biol Med (Maywood) 240(3): 305-314, 2015. PMID: 25681467. DOI: $10.1177 / 1535370214561953$

93 Jin Y, Liu Y, Zhang J, Huang W, Jiang H, Hou Y, Xu C, Zhai C, Gao X, Wang S, Wu Y, Zhu H and Lu S: The expression of miR375 is associated with carcinogenesis in three subtypes of lung cancer. PLoS One 10(12): e0144187, 2015. PMID: 26642205. DOI: 10.1371/journal.pone.0144187

94 Chamberlain PP, Sandberg ML, Sauer K, Cooke MP, Lesley SA and Spraggon G: Structural insights into enzyme regulation for inositol 1,4,5-trisphosphate 3-kinase B. Biochemistry 44(44): 14486-14493, 2005. PMID: 16262249. DOI: 10.1021/bi051256q

95 Irvine RF and Schell MJ: Back in the water: the return of the inositol phosphates. Nat Rev Mol Cell Biol 2(5): 327-338, 2001. PMID: 11331907. DOI: 10.1038/35073015

96 Sauer K and Cooke MP: Regulation of immune cell development through soluble inositol-1,3,4,5-tetrakisphosphate. Nat Rev Immunol 10(4): 257-271, 2010. PMID: 20336153. DOI: $10.1038 /$ nri2 2745

$97 \mathrm{Yu}$ JG, Ji CH and Shi MH: MicroRNA-26b suppresses tumorigenicity and promotes apoptosis in small cell lung cancer cells by targeting myeloid cell leukemia 1 protein. Kaohsiung $\mathrm{J}$ Med Sci 34(11): 593-605, 2018. PMID: 30392566. DOI: 10.1016/j.kjms.2018.06.005

98 Quinn BA, Dash R, Azab B, Sarkar S, Das SK, Kumar S, Oyesanya RA, Dasgupta S, Dent P, Grant S, Rahmani M, Curiel DT, Dmitriev I, Hedvat M, Wei J, Wu B, Stebbins JL, Reed JC, Pellecchia M, Sarkar D and Fisher PB: Targeting Mcl-1 for the therapy of cancer. Expert Opin Investig Drugs 20(10): 1397-1411, 2011. PMID: 21851287. DOI: $10.1517 / 13543784.2011 .609167$

99 Perciavalle RM and Opferman JT: Delving deeper: MCL-1's contributions to normal and cancer biology. Trends Cell Biol 23(1): 22-29, 2013. PMID: 23026029. DOI: 10.1016/j.tcb. 2012.08.011

100 Xiang W, Yang CY and Bai L: MCL-1 inhibition in cancer treatment. Onco Targets Ther 11: 7301-7314, 2018. PMID: 30425521. DOI: 10.2147/OTT.S146228

101 Yasuda Y, Ozasa H, Kim YH, Yamazoe M, Ajimizu H, Yamamoto Funazo T, Nomizo T, Tsuji T, Yoshida H, Sakamori Y, Nakajima N, Menju T, Yoshizawa A, Date H and Hirai T: MCL1 inhibition is effective against a subset of small-cell lung cancer with high MCL1 and low BCL- $\mathrm{X}_{\mathrm{L}}$ expression. Cell Death Dis 11(3): 177, 2020. PMID: 32152266. DOI: 10.1038/s41419-020-2379-2

102 Miko E, Margitai Z, Czimmerer Z, Várkonyi I, Dezso B, Lányi A, Bacsó $\mathrm{Z}$ and Scholtz B: miR-126 inhibits proliferation of small cell lung cancer cells by targeting SLC7A5. FEBS Lett 585(8): 1191-1196, 2011. PMID: 21439283. DOI: 10.1016/j.febslet.2011.03.039

103 Salisbury TB and Arthur S: The regulation and function of the L-type amino acid transporter 1 (LAT1) in cancer. Int J Mol Sci 19(8): 2373, 2018. PMID: 30103560. DOI: 10.3390/ijms 190 82373

104 Häfliger P and Charles RP: The L-type amino acid transporter LAT1-An emerging target in cancer. Int J Mol Sci 20(10): 2428, 2019. PMID: 31100853 . DOI: $10.3390 /$ ijms 20102428

$105 \mathrm{Lu}$ X: The role of large neutral amino acid transporter (LAT1) in cancer. Curr Cancer Drug Targets 19(11): 863-876, 2019. PMID: 31376820. DOI: $10.2174 / 1568009619666190802135714$

106 Nicklin P, Bergman P, Zhang B, Triantafellow E, Wang H, Nyfeler B, Yang H, Hild M, Kung C, Wilson C, Myer VE, MacKeigan JP, Porter JA, Wang YK, Cantley LC, Finan PM and Murphy LO: Bidirectional transport of amino acids regulates mTOR and autophagy. Cell 136(3): 521-534, 2009. PMID: 19203585. DOI: 10.1016/j.cell.2008.11.044

107 Pardo OE, Arcaro A, Salerno G, Tetley TD, Valovka T, Gout I and Seckl MJ: Novel cross talk between MEK and S6K2 in FGF2 induced proliferation of SCLC cells. Oncogene 20(52): 76587667, 2001. PMID: 11753643. DOI: 10.1038/sj.onc.1204994 
$108 \mathrm{Xu} \mathrm{H}$, Cai T, Carmona GN, Abuhatzira L and Notkins AL: Small cell lung cancer growth is inhibited by miR-342 through its effect of the target gene IA-2. J Transl Med 14(1): 278, 2016. PMID: 27670444. DOI: 10.1186/s12967-016-1036-0

109 Song P, Sekhon HS, Jia Y, Keller JA, Blusztajn JK, Mark GP and Spindel ER: Acetylcholine is synthesized by and acts as an autocrine growth factor for small cell lung carcinoma. Cancer Res 63(1): 214-221, 2003. PMID: 12517800.

$110 \mathrm{Xie}$ H, Notkins AL and Lan MS: IA-2, a transmembrane protein tyrosine phosphatase, is expressed in human lung cancer cell lines with neuroendocrine phenotype. Cancer Res 56(12): 27422744, 1996. PMID: 8665506.

111 Lan MS, Lu J, Goto Y and Notkins AL: Molecular cloning and identification of a receptor-type protein tyrosine phosphatase, IA2, from human insulinoma. DNA Cell Biol 13(5): 505-514, 1994 PMID: 8024693. DOI: 10.1089/dna.1994.13.505

$112 \mathrm{Hu}$ YF, Zhang HL, Cai T, Harashima S and Notkins AL: The IA2 interactome. Diabetologia 48(12): 2576-2581, 2005. PMID 16273344. DOI: $10.1007 / \mathrm{s} 00125-005-0037-y$

113 Gao F, Wu H, Wang R, Guo Y, Zhang Z, Wang T, Zhang G, Liu $\mathrm{C}$ and Liu J: MicroRNA-485-5p suppresses the proliferation, migration and invasion of small cell lung cancer cells by targeting flotillin-2. Bioengineered 10(1): 1-12, 2019. PMID: 30836864. DOI: $10.1080 / 21655979.2019 .1586056$

114 Gauthier-Rouvière C, Bodin S, Comunale F and Planchon D: Flotillin membrane domains in cancer. Cancer Metastasis Rev 39(2): 361-374, 2020. PMID: 32297092. DOI: 10.1007/s10555020-09873-y

115 Liu XX, Liu WD, Wang L, Zhu B, Shi X, Peng ZX, Zhu HC, Liu XD, Zhong MZ, Xie D, Zeng MS and Ren CP: Roles of flotillins in tumors. J Zhejiang Univ Sci B 19(3): 171-182, 2018. PMID: 29504311. DOI: 10.1631/jzus.B1700102

116 Liu FT, Qu QG and Zhu ZM: Up-regulation of Flot-2 protein is related to lymph node metastasis and poor prognosis in human solid tumors. Minerva Chir 72(2): 146-156, 2017. PMID: 27981826. DOI: $10.23736 / S 0026-4733.16 .07261-8$

117 Liu R, Zhang L, Xu Z and Cui Y: [MiR-665 promotes the biological behavior of small cell lung cancer by targeting LLGL1]. Zhongguo Fei Ai Za Zhi 23(4): 223-232, 2020. PMID: 32222154. DOI: 10.3779/j.issn.1009-3419.2020.104.03

118 Tsuruga T, Nakagawa S, Watanabe M, Takizawa S, Matsumoto Y, Nagasaka K, Sone K, Hiraike H, Miyamoto Y, Hiraike O, Minaguchi T, Oda K, Yasugi T, Yano T and Taketani Y: Loss of Hugl-1 expression associates with lymph node metastasis in endometrial cancer. Oncol Res 16(9): 431-435, 2007. PMID: 18074678. DOI: $10.3727 / 000000007783980855$

119 Song J, Peng XL, Ji MY, Ai MH, Zhang JX and Dong WG: Hugl1 induces apoptosis in esophageal carcinoma cells both in vitro and in vivo. World J Gastroenterol 19(26): 4127-4136, 2013. PMID: 23864775. DOI: 10.3748/wjg.v19.i26.4127

120 Schimanski CC, Schmitz G, Kashyap A, Bosserhoff AK, Bataille F, Schäfer SC, Lehr HA, Berger MR, Galle PR, Strand S and Strand D: Reduced expression of Hugl-1, the human homologue of Drosophila tumour suppressor gene $\mathrm{lgl}$, contributes to progression of colorectal cancer. Oncogene 24(19): 3100-3109, 2005. PMID: 15735678. DOI: 10.1038/sj.onc. 1208520

121 Kuphal S, Wallner S, Schimanski CC, Bataille F, Hofer P, Strand S, Strand D and Bosserhoff AK: Expression of Hugl-1 is strongly reduced in malignant melanoma. Oncogene 25(1): 103-110, 2006 PMID: 16170365. DOI: 10.1038/sj.onc.1209008
122 Desuki A, Staib F, Gockel I, Moehler M, Lang H, Biesterfeld S, Maderer A, Galle PR, Berger MR and Schimanski CC: Loss of $L L G L 1$ expression correlates with diffuse gastric cancer and distant peritoneal metastases. Can J Gastroenterol Hepatol 2019: 2920493, 2019. PMID: 31058107. DOI: $10.1155 / 2019 / 2920493$

123 Matsuzaki T, Takekoshi S, Toriumi K, Kitatani K, Nitou M, Imamura N, Ogura G, Masuda R, Nakamura N and Iwazaki M: Reduced expression of Hugl 1 contributes to the progression of lung squamous cell carcinoma. Tokai J Exp Clin Med 40(4): 169177, 2015. PMID: 26662669.

124 Sun Y, Hu B, Wang Y, Li Z, Wu J, Yang Y, Wei Y, Peng X, Chen H, Chen R, Jiang P, Fang S, Yu Z and Guo L: miR-216a-5p inhibits malignant progression in small cell lung cancer: involvement of the Bcl-2 family proteins. Cancer Manag Res 10: 4735-4745, 2018. PMID: 30425570. DOI: 10.2147/CMAR.S178380

125 Ben-Ezra JM, Kornstein MJ, Grimes MM and Krystal G: Small cell carcinomas of the lung express the Bcl-2 protein. Am J Pathol 145(5): 1036-1040, 1994. PMID: 7977636.

126 Jiang SX, Sato Y, Kuwao S and Kameya T: Expression of bcl-2 oncogene protein is prevalent in small cell lung carcinomas. J Pathol 177(2): 135-138, 1995. PMID: 7490679. DOI: $10.1002 /$ path.1711770206

127 Lochmann TL, Floros KV, Naseri M, Powell KM, Cook W, March RJ, Stein GT, Greninger P, Maves YK, Saunders LR, Dylla SJ, Costa C, Boikos SA, Leverson JD, Souers AJ, Krystal GW, Harada $\mathrm{H}$, Benes $\mathrm{CH}$ and Faber AC: Venetoclax is effective in small-cell lung cancers with high BCL-2 expression. Clin Cancer Res 24(2): 360-369, 2018. PMID: 29118061. DOI: 10.1158/10780432.CCR-17-1606

128 Lochmann TL, Bouck YM and Faber AC: BCL-2 inhibition is a promising therapeutic strategy for small cell lung cancer. Oncoscience 5(7-8): 218-219, 2018. PMID: 30234143. DOI: $10.18632 /$ oncoscience. 455

129 Gong M, Ma J, Guillemette R, Zhou M, Yang Y, Yang Y, Hock JM and Yu X: miR-335 inhibits small cell lung cancer bone metastases via IGF-IR and RANKL pathways. Mol Cancer Res 12(1): 101-110, 2014. PMID: 23966614. DOI: 10.1158/15417786.MCR-13-0136

130 Riedemann $\mathrm{J}$ and Macaulay VM: IGF1R signalling and its inhibition. Endocr Relat Cancer 13 Suppl 1: S33-S43, 2006. PMID: 17259557. DOI: 10.1677/erc.1.01280

131 Hiraga T, Myoui A, Hashimoto N, Sasaki A, Hata K, Morita Y, Yoshikawa H, Rosen CJ, Mundy GR and Yoneda T: Bone-derived IGF mediates crosstalk between bone and breast cancer cells in bony metastases. Cancer Res 72(16): 4238-4249, 2012. PMID: 22738911. DOI: 10.1158/0008-5472.CAN-11-3061

132 Weidle UH, Birzele F, Kollmorgen G and Rüger R: Molecular mechanisms of bone metastasis. Cancer Genomics Proteomics 13(1): 1-12, 2016. PMID: 26708594.

133 Dougall WC: Molecular pathways: osteoclast-dependent and osteoclast-independent roles of the RANKL/RANK/OPG pathway in tumorigenesis and metastasis. Clin Cancer Res 18(2): 326-335, 2012. PMID: 22031096. DOI: $10.1158 / 1078-0432$.CCR-10-2507

134 Yin JJ, Pollock CB and Kelly K: Mechanisms of cancer metastasis to the bone. Cell Res 15(1): 57-62, 2005. PMID: 15686629. DOI: $10.1038 /$ sj.cr.7290266

135 Liu F, Yu X, Huang H, Chen X, Wang J, Zhang X and Lin Q: Upregulation of microRNA-450 inhibits the progression of lung cancer in vitro and in vivo by targeting interferon regulatory factor 
2. Int J Mol Med 38(1): 283-290, 2016. PMID: 27246609. DOI: 10.3892/ijmm.2016.2612

136 Yanai $\mathrm{H}$, Negishi $\mathrm{H}$ and Taniguchi T: The IRF family of transcription factors: Inception, impact and implications in oncogenesis. Oncoimmunology 1(8): 1376-1386, 2012. PMID: 23243601. DOI: 10.4161 /onci.22475

137 Taniguchi T, Ogasawara K, Takaoka A and Tanaka N: IRF family of transcription factors as regulators of host defense. Annu Rev Immunol 19: 623-655, 2001. PMID: 11244049. DOI: 10.1146/annurev.immunol.19.1.623

138 Nguyen H, Mustafa A, Hiscott J and Lin R: Transcription factor IRF-2 exerts its oncogenic phenotype through the DNA binding/transcription repression domain. Oncogene 11(3): 537544, 1995. PMID: 7630638.

139 Vaughan PS, van der Meijden CM, Aziz F, Harada H, Taniguchi T, van Wijnen AJ, Stein JL and Stein GS: Cell cycle regulation of histone $\mathrm{H} 4$ gene transcription requires the oncogenic factor IRF2. J Biol Chem 273(1): 194-199, 1998. PMID: 9417064. DOI: $10.1074 / j b c .273 .1 .194$

140 Liao W, Overman MJ, Boutin AT, Shang X, Zhao D, Dey P, Li J, Wang G, Lan Z, Li J, Tang M, Jiang S, Ma X, Chen P, Katkhuda R, Korphaisarn K, Chakravarti D, Chang A, Spring DJ, Chang Q, Zhang J, Maru DM, Maeda DY, Zebala JA, Kopetz S, Wang YA and DePinho RA: KRAS-IRF2 axis drives immune suppression and immune therapy resistance in colorectal cancer. Cancer Cell 35(4): 559-572.e7, 2019. PMID: 30905761. DOI: 10.1016/j.ccell. 2019.02.008

141 Shen J, Zhou W, Bi N, Song YM, Zhang FQ, Zhan QM and Wang LH: MicroRNA-886-3P functions as a tumor suppressor in small cell lung cancer. Cancer Biol Ther 19(12): 1185-1192, 2018. PMID: 30230945. DOI: 10.1080/15384047.2018.1491505

142 Santamaria PG, Moreno-Bueno G, Portillo F and Cano A: EMT: Present and future in clinical oncology. Mol Oncol 11(7): 718738, 2017. PMID: 28590039. DOI: 10.1002/1878-0261.12091

143 Kalluri R and Weinberg RA: The basics of epithelialmesenchymal transition. J Clin Invest 119(6): 1420-1428, 2009. PMID: 19487818. DOI: 10.1172/JCI39104

144 Liu H, Zhang X, Li J, Sun B, Qian H and Yin Z: The biological and clinical importance of epithelial-mesenchymal transition in circulating tumor cells. J Cancer Res Clin Oncol 141(2): 189-201, 2015. PMID: 24965746. DOI: 10.1007/s00432-014-1752-x

145 Nguyen DD and Chang S: Development of novel therapeutic agents by inhibition of oncogenic MicroRNAs. Int J Mol Sci 19(1): 65, 2017. PMID: 29280958. DOI: 10.3390/ijms19010065
146 Ling H, Fabbri M and Calin GA: MicroRNAs and other noncoding RNAs as targets for anticancer drug development. Nat Rev Drug Discov 12(11): 847-865, 2013. PMID: 24172333. DOI: $10.1038 / \mathrm{nrd} 4140$

147 Gambari R, Brognara E, Spandidos DA and Fabbri E: Targeting oncomiRNAs and mimicking tumor suppressor miRNAs: New trends in the development of miRNA therapeutic strategies in oncology (Review). Int J Oncol 49(1): 5-32, 2016. PMID: 27175518. DOI: $10.3892 /$ ijo.2016.3503

148 Broderick JA and Zamore PD: MicroRNA therapeutics. Gene Ther 18(12): 1104-1110, 2011. PMID: 21525952. DOI: $10.1038 /$ gt.2011.50

149 Juliano RL, Ming X and Nakagawa O: Cellular uptake and intracellular trafficking of antisense and siRNA oligonucleotides. Bioconjug Chem 23(2): 147-157, 2012. PMID: 21992697. DOI: $10.1021 / \mathrm{bc} 200377 \mathrm{~d}$

150 Malek A, Merkel O, Fink L, Czubayko F, Kissel T and Aigner A: In vivo pharmacokinetics, tissue distribution and underlying mechanisms of various PEI(-PEG)/siRNA complexes. Toxicol Appl Pharmacol 236(1): 97-108, 2009. PMID: 19371615. DOI: 10.1016/j.taap.2009.01.014

151 Dowdy SF: Overcoming cellular barriers for RNA therapeutics. Nat Biotechnol 35(3): 222-229, 2017. PMID: 28244992. DOI: $10.1038 /$ nbt.3802

152 Bennett CF: Therapeutic antisense oligonucleotides are coming of age. Annu Rev Med 70: 307-321, 2019. PMID: 30691367. DOI: 10.1146/annurev-med-041217-010829

153 Saliminejad K, Khorram Khorshid HR, Soleymani Fard S and Ghaffari SH: An overview of microRNAs: Biology, functions, therapeutics, and analysis methods. J Cell Physiol 234(5): 54515465, 2019. PMID: 30471116. DOI: 10.1002/jcp.27486

154 Lee SWL, Paoletti C, Campisi M, Osaki T, Adriani G, Kamm RD, Mattu $\mathrm{C}$ and Chiono V: MicroRNA delivery through nanoparticles. J Control Release 313: 80-95, 2019. PMID: 31622695. DOI: 10.1016/j.jconrel.2019.10.007

155 Jones D: Setbacks shadow microRNA therapies in the clinic. Nat Biotechnol 36(10): 909-910, 2018. PMID: 30307922. DOI: 10.1038/nbt1018-909
Received June 16, 2021

Revised July 13, 2021

Accepted July 15, 2021 